\title{
Innovation strategies of manufacturing companies during expansions and slowdowns
}

\author{
Jagoda Kaszowska-Mojsa
}

\section{A B S T R A C T}

Objective: The aim of the article is to analyse the differentiation in the innovation strategies of the manufacturing companies during economic expansions and slowdowns.

Research Design \& Methods: The random-effect logistic regression models were used to examine the differentiation of a firm's innovation strategies and the probability of innovating in different phases of the business cycle. I used the proprietary Innovation Survey (PNT-02) data, which overlap with the Community Innovation Survey (CIS).

Findings: The analyses suggest that the likelihood of implementing innovation changes with the deterioration of macroeconomic conditions. There are groups of manufacturing firms in Poland whose innovation activities are procyclical and countercyclical.

Implications \& Recommendations: My analyses will help to understand the innovation strategies of the firms. This, in turn, should help to direct public support where it can be used more effectively. The recommendations will be relevant for the National Innovation System in Poland, as they should counterbalance the procyclical impact of a slowdown on a firm's innovation spending and cooperation in innovation activities.

Contribution \& Value Added: Previously, the PNT-02 data for 2004-2006 and 20062008 were used in the FP6 project on micro determinants of growth (MICRODYN) to identify the barriers to the innovation of the firms and the factors that decreased the probability of firms' innovativeness. This study indicated a differentiation of the competences between firms that implemented innovation in two periods compared to those that only did so in one period. However, the previous study did not cover a period of an economic slowdown. Therefore, this study will contribute to the state-of-the-art literature by extending the analyses to this period.

\begin{tabular}{|c|c|}
\hline $\begin{array}{l}\text { Article type: } \\
\text { Keywords: }\end{array}$ & $\begin{array}{l}\text { research article } \\
\text { innovation strategies; manufacturing sector; CIS survey; slowdown; } \\
\text { procyclicality; countercyclicality }\end{array}$ \\
\hline JEL codes: & 031,032 \\
\hline Received: 7 & Accepted: 10 August 2020 \\
\hline
\end{tabular}

\section{Suggested citation:}

Kaszowska-Mojsa, J. (2020). Innovation strategies of manufacturing companies during expansions and slowdowns. Entrepreneurial Business and Economics Review, 8(4), 47-66. https://doi.org/10.15678/EBER.2020.080403 


\section{INTRODUCTION}

The aim of this study is to analyse the innovation activities and differentiation in the strategies of Polish manufacturing companies in the period between 2004 and 2014. For this one decade, we attempt to answer the question of whether the innovation activities and strategies were affected by the changes in the macroeconomic conditions in different phases of the business and financial cycles or whether they were affected only by the supply side factors. The purpose of the article is not to identify the properties of the business cycle nor to study its synchronization with the financial cycle. The information about phases of business and financial cycles in Poland was described in previous publications (Lenart \& Pipień, 2013a; Pipień, Wdowiński, \& Kaszowska, 2018). We assume that the period of 2004-2008 corresponds to economic prosperity in Poland, 2008-2010 to slowdown, while 2010-2012 corresponds to the recovery, and 2012-2014 to the expansionary phase of the business cycle. This article attempts to show what conclusions about changes in the innovation activity and strategies of the companies for specific periods can be drawn based on the CIS ('PNT-02') survey. I would also like to indicate which studies based on the Statistics Poland data could be conducted in the future.

The term 'innovation', as defined in the OECD Oslo Manual (2005), covers a wide range of phenomena. As in both the economics and management traditions, we assume that the accumulation of knowledge - its sources, factors and forms, i.e. supply factors - play a key role in a firm's innovation activities and strategies. However, because we intend to analyse the impact of changes in the macro environment on the innovation strategies of firms, we have to consider the role of the demand factors as well. Those factors influence the innovation activities and the use of innovation resources. Changes in the macroeconomic environment have an impact on the changes in the competition and innovative strategies, the demography of innovative firms and their typology, as well as on the differentiation of their innovation strategies. We also show that the phase of the business cycle influences the sources, factors, and forms in which knowledge is accumulated and hence the probability of introducing innovation.

In the analyses, I used disaggregated data from the Statistics Poland survey. The PNT02 survey contains information on the innovation activities of the firms that participate in the Community of Innovation Survey (CIS). The analysis of the extensive database required the use of statistical and econometric methods, including the estimation of logistic regression models. During the estimation of the models, among other things, I tested the impact of crises and changes in internal funds and external financing on the probability of implementing innovation. The availability of external financing, including loans, is one of the main factors that influenced the innovation activity of enterprises in Poland and the differentiation of their strategies during the global crisis of 2008.

Previously, the PNT-02 data for 2004-2006 and 2006-2008 - along with a questionnaire for two groups of the firms from four sectors in Poland, the Czech Republic, and Hungary were used in the EU FP6 project MICRODYN to identify the barriers to a firm's innovation and factors that decreased the probability of it being innovative. This previous study indicated a differentiation of the competences between the firms that implemented innovation in two periods compared to those firms that did so in only one period. However, this study did not cover the period of an economic slowdown. We contribute to the state-of-the-art 
literature by providing information on the differentiation of firms' innovation strategies and activities throughout the business cycle. Another value added of the study is the identification of the barriers to innovation in the different phases of the business cycle.

Firstly, I present a literature review and discuss hypotheses. The next section explains how the composite indicator of a firm's strategy was constructed and presents the results of computation based on a sample of firms. Specific results of innovation from the $\mathrm{CIS}$ survey (PNT-02) appear in the appendix (available in external repository). The following section explains the details of random-effect logistic regression models on short panel data, along with the results of estimation of two models. The last section concludes.

\section{LITERATURE REVIEW}

\section{The Differentiation of a Firm's Innovation Strategies}

The problem of the differentiation of innovation strategies is a key element of the discussion between mainstream researchers and those that represent an evolutionary tradition. Evolutionary approaches, strategic management, and the Austrian business cycle theory focus on the differentiation of sources, factors, and the forms in which knowledge is accumulated among firms and over time, which shape the innovation strategies of the firms and their behaviour on the market (Mintzberg, 1988). In light of this tradition, we aim to identify the relationship between the features of the knowledge accumulation mechanism, its use (innovation strategy), and the innovation activity of the firms in an upswing and in a slowdown.

The evolutionary perspective primarily focuses on the supply side of innovation. However, this study not only adopted the supply-side approach but also the demand one. I assumed that an external shock - such as a decrease in market demand during an economic slowdown - can make the introduction of innovation harder, even when accounting for a greater knowledge accumulation of a firm. Therefore, an external shock may cause a change in a firm's innovation strategy. The impact of the changes in demand has been neglected in the literature. The objective of this study is to fill the gap in the literature and to provide insights on the differentiation of a firm's innovation strategies during different phases of the business cycle, which far exceeds the current state-of-the-art literature.

Although the diversity of a firm's innovation strategy constitutes one of the three pillars of the evolutionary perspective, an empirical analysis of this problem has only recently been undertaken. Its main directions reflect two approaches: a sectoral or a micro-economic approach. Within the sectoral approach, two streams of research emerged. Both of these posit that the innovation strategy of a firm is determined by the characteristics of its sector. Pavitt's (1984) taxonomy of industries paves the way for the first stream (Peneder, 2003; de Jong \& Marsili, 2006; Leiponen \& Drejer, 2007; Castellaci, 2008). In the second one, the OECD classifies industries according to their technological intensity.

Subsequent studies (e.g. Srholec \& Verspagen, 2008) undermine the conclusion that the differences in the innovation strategies among the sectors exceed those among firms. A subsequent micro-economic research shows the differentiation of a firm's innovation strategies in some EU countries (Wziątek-Kubiak, Balcerowicz, \& Pęczkowski, 2013a). In the empirical literature, there are two main approaches that deal with this issue. Both are extensions of the evolutionary approaches. The first one (Llerena \& Oltra, 2002; 
Damanpour \& Wischnevsky, 2006; Jensen, Johnson, Lorenz, \& Lundvall, 2007) focuses on the internal and external sources of innovation. While the second one (Leiponen \& Dreijer, 2007; Srholec \& Verspagen, 2008; Peneder, 2003; Som, Dreher, \& Maloca, 2010; for an overview of some studies on innovation modes, see Frentz and Lambert, 2010) uses a cluster analysis to select different innovation strategies. Most of them are based on the data from the Community Innovation Survey (CIS). This pool of research differs with respect to the period of the analysis, a company's activities (manufacturing and/or services), and the variables that are used. These analyses raised the issue of innovation persistence, which was analysed in certain countries. The non-availability of the micro-data for Polish firms implied that the issue of innovation persistence could not be studied for Polish firms.

The literature on the impact of a crisis or economic slowdown on the innovation behaviour of the firms is surprisingly scarce. Despite the Schumpeterian origin of the evolutionary perspective, the above-mentioned topic was rarely undertaken (Antonioli, Bianchi, Mazzanti, Montresor, \& Pini, 2011). To date, research on the relationship between the innovation behaviour of the firms and changes in the business cycle has shown a very strong sensitivity of the innovation activities of the firms in the EU New Member States to an external shock such as an economic slowdown (Archibugi \& Filippetti, 2011, 2012; Archibugi, Filippetti, \& Fenz 2012, 2013, 2013a, 2013b; Correa \& Lootty 2010; Wziątek-Kubiak, \& Pęczkowski, 2013; Holl \& Roma, 2016; Hardy \& Sever, 2020, Giebel \& Kraft 2017). This suggests that the level of knowledge accumulation influences the sensitivity of the innovation activities of the firms to changes in the business cycle.

In order to explain the impact of changes in macroeconomic conditions on the mechanisms of knowledge accumulation and its different use among companies, I formed four main hypotheses:

H1: Changes in the macroeconomic conditions in respective phases of business cycle affect the demographics of innovative firms; their composition, characteristics, and number within the total number of companies.

H2: Companies use different factors and forms of knowledge accumulation and sources of funding during economic expansions and slowdowns.

H3: The macroeconomic conditions affect external funding, cooperation, the research and development process and they enhance the role of obstacles to innovations, which translates into a lower probability of introducing innovations during a slowdown.

H4: Changes in the macroeconomic conditions contribute to the differentiation of the innovation strategies between and within groups of companies, which is indicated by the typology of the firms that is based on the continuity of innovation activity.

Because we assume that firms are heterogeneous in their innovation resources, they can also differ in the continuity of their innovation activities and the strategies that they introduce. Some of them - persistent innovators - innovate continuously, while others occasional innovators - from time to time, only during an economic upswing. However, it is also possible that some firms that were previously not innovators begin their innovation activities irrespective of a slowdown. They are considered to be challengers. Therefore, I 
introduce a new typology of innovative firms (persistent innovators, occasional innovators, and challengers) and compare their innovation strategies, i.e. factors, sources, and the types of innovation that they use in different phases of the business cycle.

\section{RESEARCH METHODOLOGY}

\section{Results of the CIS (PNT-02) Innovation Survey and the Oslo Manual}

In the study, the third edition of OECD Oslo Manual was used as the international reference guide for collecting and using data on innovation. According to the Manual, an innovation is the implementation of a new or significantly improved product (good or service), process, marketing method, or organizational method in business practices, workplace organizations, or external relations. Hence, the Oslo Manual distinguishes four areas of innovation: product, process, marketing, and organizational innovations; and so does the CIS (PNT-02) survey. A common feature of an innovation is that it must have been implemented, i.e. a new or improved product must have been introduced on the market. New processes, marketing methods, or organizational methods are implemented when they are brought into actual use in a firm's operations.

The Statistics Poland survey was focused on the manufacturing sector. In this study, an innovative company was assumed to be one that had implemented an innovation during the period under review. The aim of the Statistics Poland survey was to identify and describe firms' innovation activities, i.e. all of the scientific, technological, organizational, financial, and commercial steps that actually lead to (or are intended to) implementing the innovations. This includes research and development that is not directly related to the development of a specific innovation (Oslo Manual 2005).

The PNT-02 survey overlaps with the cyclically performed Community of Innovation Survey (CIS). We used the databases of disaggregated data for both an upswing and slowdown in Poland during the decade between 2004 and 2014. The PNT-02 databases consist of a voluntary survey of the entire population of large and medium-sized enterprises and a random sample survey of small enterprises. The surveys are conducted every two years for a period of three consecutive years.

Firstly, I performed statistical analysis on the entire sample for each period. Secondly, I determined how these data can be used to develop a complex algorithm that translates the information that is provided in the data into an indicator of innovation strategy, which is much easier to interpret. The values of an indicator suggest whether the firm is more likely to develop innovations on their own or whether it is more prone to purchase a product, process, or technology that is developed externally in order to improve their own product or simply to imitate it in the future. Thirdly, I performed an econometric analysis to identify the supply-side and demand-side factors that affect the likelihood of innovation. In order to perform this analysis, I constructed a balanced panel of 3691 enterprises that had reported in all five surveys in 2004-2014. Using the panel data, I estimated the random-effect logistic regression. Then, I determined how the values of our indicator were related to the probability of innovation. Finally, I attempted to determine which companies were persistent innovators, which were challengers, and which firms were occasional innovators. 


\section{Composite Indicator of a Firms' Strategy}

The PNT-02 data can be used to analyse a firm's innovation strategy on the market. I present a composite indicator of the innovation and commercialization strategy of the firms on the market (1).

where:

$$
I_{j}=\frac{\sum_{j=1}^{N} S_{j} \times \omega_{j}}{\sum_{j=1}^{N} \omega_{j}}
$$

$S_{j}$ - subindicator for category $\mathrm{j}$ of the questions from the PNT-02 survey;

$N$ - number of categories of questions from the PNT-02 survey that were considered;

$\omega$ - significance of the specific component in the question.

The values of the indicator $I_{j}$ ranged from minus one to one. A value equal to minus one should be interpreted as a willingness to purchase solutions that have already been developed from other enterprises and institutions, including research centres. On the other hand, a value of one should be understood as the interest of company in creating new solutions on their own and in commercialising these innovations on the market. Values close to zero should be interpreted as indicating a neutral attitude towards innovation, i.e. that a given firm is not particularly interested in implementing an innovation in a given period.

When constructing the indicators, the answers to 56 questions from the PNT-02 survey were taken into account. The questions were divided into the following categories:

1. Product and process innovations in the past (innovation persistence):

Data on introducing new or significantly improved products, services, production methods, supply and distribution methods, or systems to support the processes by an enterprise in previous period.

2. Sales of new or significantly improved products and processes:

- Share of revenues from selling new or significantly improved goods and services in the total sales revenues in the previous period;

- Share of revenues from selling new or significantly improved export goods in the total sales revenues in the previous period.

3. Perception of the improvements and modifications used by the company:

Data on whether a product or process was new or significantly improved from the perspective of the enterprise or in general on the market in which it operates.

4. Information regarding the institution that developed the product or process innovation and cooperation between institutions:

Data regarding the type of institutions that developed the product or process innovation: enterprise or group of enterprises, enterprise in cooperation with other national scientific enterprises or institutions, enterprise in cooperation with foreign enterprises and scientific institutions, mainly foreign or mainly domestic enterprises.

5. Prematurely terminated or unfinished projects:

Binary data on whether a company was involved in a product or process innovation projects that were prematurely terminated or unfinished. 
6. Expenditures:

Data on expenditures on the R\&D that had been conducted in the entity (internally) or externally on an occasional or continuous basis, acquisition of machinery and technical equipment, expenditures on transporting tools, instruments, movables, software, purchase of technology in the form of documentation and rights, staff training directly related to the introduction of an innovation, marketing related to the introduction of new or significantly improved products.

7. Funding and financial support:

Data on financial support for the innovation activities, including R\&D, from local and central government and from EU funds.

8. Effects of the innovation activities:

Data on the positive and negative effects of the innovation activities in a given period, i.e. increasing the range, entering new markets or increasing the share in existing markets, improving product quality, increasing production flexibility, increasing production capacity, reducing labour costs per product unit, reducing material consumption per product unit, reducing harmfulness to the environment, improving occupational health and safety, and compliance with regulations, norms, and standards.

9. Commercialisation:

Data on the purchase and sale of licences, $R \& D$, automation measures, and consulting services.

Firstly, an algorithm was developed that used logic formulas to read the non-unified data from the databases and to calculate specific values based on them. For each category described above, questions were specified. For instance, if a company provided a positive answer to the question 'Did your company purchase R\&D from external sources?', the value of the subindicator was decreased by one. Alternatively, if a positive answer was given to the answer stating that the company had sold $R \& D$, then the value of the subindicator was increased by one. A subindicator is the sum of the values that had been reported for all of the questions in the category, but this sum can only be computed after applying an algorithm that teaches the machine how to interpret a specific piece of data. The value of an indicator is the weighted average of the values of the subindicators. The weights enable the values of the subindicators to be normalised, so that each question has the same importance. The weights can easily be modified to assign a different importance of the categories (questions). The indicator values can be calculated for all of the companies and periods (Figures 1-2).

The values of the indicators for 2004-2006 were concentrated in the range $(-0.05,0)$, i.e. $61.19 \%$ of the companies were more willing to buy ready-made innovative solutions from other enterprises and scientific institutions or to suspend their innovation activity in the current period than to create new solutions and commercialise them on the market. The indicator values for $1.93 \%$ of the companies were lower than -0.05 , which means that these companies were even more willing to buy ready-made solutions. In total, $36.88 \%$ of the companies declared values ranging from 0.05 to 0.79 ; see Figure 1.

In 2006-2008, we observed that the values of the indicator for $66.69 \%$ of the companies ranged from $(-0.10,-0.05)$. For $0.67 \%$ of the firms, the values of the indicator were below -0.10 . Therefore, these companies were relatively more prone to buy ready-made solutions than in the previous period. The empirical distribution was asymmetrically right- 
sided. The indicator values for $32.29 \%$ of the companies were positive, with the maximum observed indicator value being higher than the one in the previous period $(0.82 \%)$. In the period preceding the crisis, companies were more likely to create new solutions and commercialise them than in the first period under study.

During the crisis, the number of companies that became neutral towards innovative activities increased. The percentage of companies that purchased innovative products decreased. The indicator values for $3.01 \%$ of the companies were below -0.05 , of which only $0.48 \%$ of the companies were below -0.1 , which indicates that - during the crisis - companies largely stopped purchasing innovative products from external sources. The indicator values for $27.82 \%$ of the firms were positive, of which the values ranged from 0.1 to 0.79 for $19.40 \%$ of companies; see Figure 1 .

In 2010-2012, values of the indicators below -0.1 were observed for $0.74 \%$ of the companies. The situation in 2012 was similar to that of $2008-2010$. For $64.09 \%$ of the companies, the indicator values fluctuated between $(-0.10,-0.05)$. For $3.82 \%$ of the companies, the values was in the range of $(-0.05,0.05)$ and, for $31.35 \%$, they fluctuated in the range of $(0.05,0.79)$; see Figure 1 .

In 2012-2014, values in the range from -0.10 to -0.05 were observed for $63.91 \%$ of the companies. Values below -0.1 were reported for $0.61 \%$ of the companies; $3.09 \%$ of the companies were practically neutral towards innovation activities, while $32.39 \%$ of the firms were more likely to create new solutions and to commercialise them (values of indicator in the range between 0.05 and 0.78 ).

To summarise, the analysis of the values of an indicator shows the full impact of the 2008-2010 crisis on the behaviour of the enterprises and their strategies. Enterprises that once bought ready-made innovative solutions on the market were more likely to remain neutral towards innovative activities or to move to developing new products and processes on their own (values of the indicators up to 0.2 ). A similar situation was observed in 20042006. However, enterprises that had already been active in implementing innovations (values of the indicators above 0.2 ) were less likely to introduce innovations during the crisis.

\section{The Random-Effect Logistic Regression Models}

In this section, I will present which individual factors influenced the probability of introducing an innovation the most. Then, I will determine what the relationship between the values of composite indicator of innovation strategy and the probability of implementing innovation could be.

I constructed a balanced panel of 3691 firms that had reported values in all five editions of the PNT-02 survey over the decade (2004-2014). The dependent variable is a binary variable ( Innov $_{i t}$ ), which is equal to one if the innovations occurred and zero if otherwise. In the panel, $55.44 \%$ of the observations were equal to zero, and $44.56 \%$ of the observations were equal to one. There was considerable persistence from period to period for the firms under study; $85.65 \%$ of those who did not innovate in one year (one period) also did not innovate in the next year (the next reporting period), while $78.04 \%$ of those who did innovate in one year also innovated in the next one. However, I also observed that $21.96 \%$ of the firms in the panel who had innovated in the first period did not do so in the following period. Moreover, $14.35 \%$ of the firms that did not innovate in one year were able to innovate in the following period; see Table 1. 

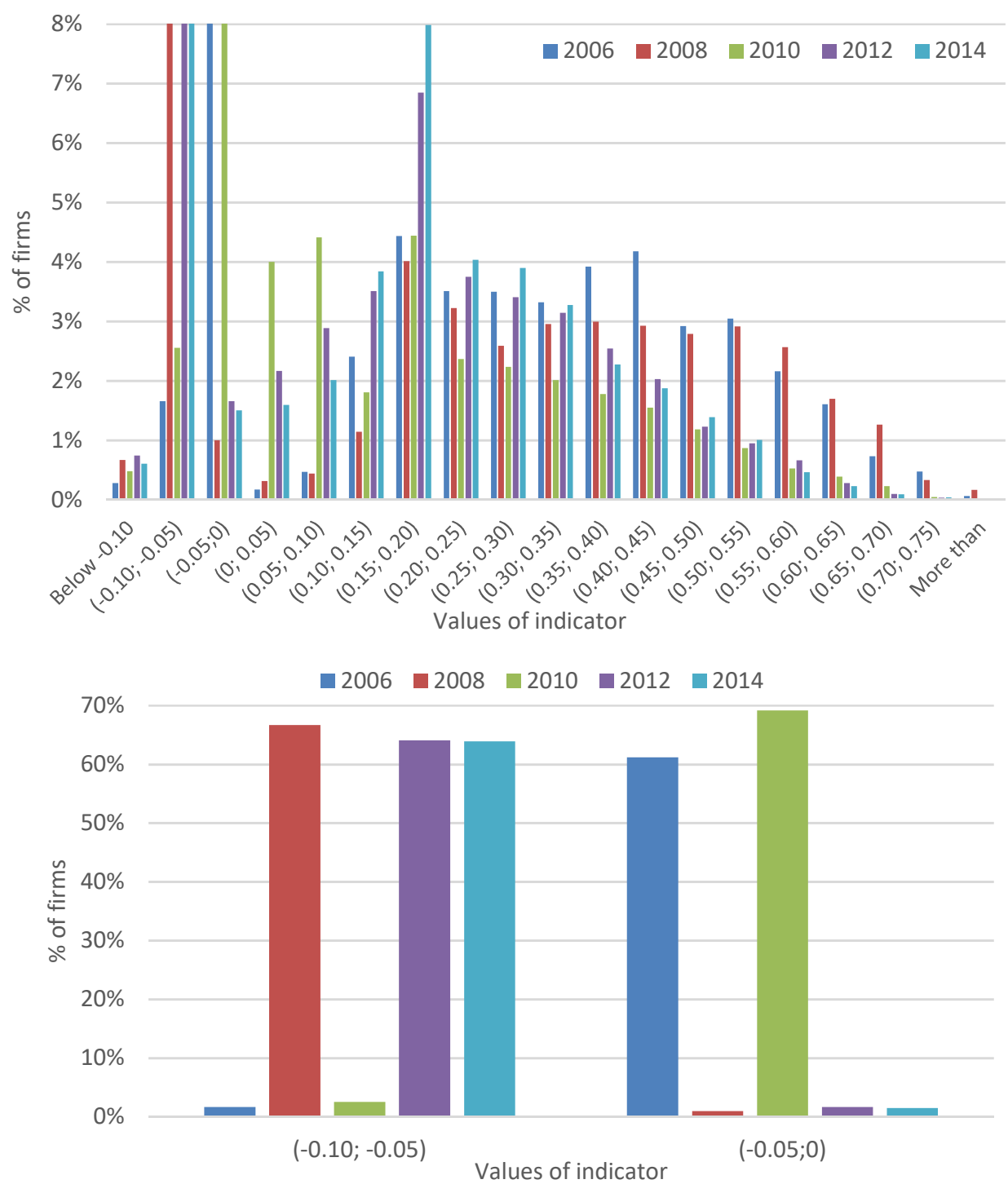

Figure 1. Values of the indicator computed for the five PNT-02 samples (histogram) Source: own elaboration based on the PNT-02 survey data.

Table 1. Period-to-period transitions in implementing innovations

\begin{tabular}{|l|c|c|c|c|}
\hline \multirow{2}{|c|}{ Variable } & \multicolumn{3}{c|}{ Innov $_{\text {it }}$} \\
\cline { 3 - 5 } & 0 & 0 & 1 & Total \\
\hline \multirow{3}{*}{ Innov $_{i t}$} & 1 & 85.65 & 14.35 & 100.00 \\
\cline { 2 - 5 } & Total & 21.96 & 78.04 & 100.00 \\
\cline { 2 - 5 } & 57.00 & 43.00 & 100.00 \\
\hline
\end{tabular}

Innov_it - binary variable. The value 1 - firm $i$ introduced innovation at time, 0 - otherwise. Source: own elaboration based on the PNT-02 data in STATA. 
The number of variables were tested in order to determine whether they were significant when estimating the random-effect logistic regression model; the list is available in the external repository where the results of the project were described in detail. Finally, the most significant explanatory power had the following variables: the group (based on Statistical Classification of Economic Activities in the European Community NACE) which the firm belongs to (NACEGR), external R\&D (RDEXT), internal R\&D (RDINT), size of the company $(S I Z E)$, external funding received in the determined period (FUND), and binary variable describing the occurrence of the crisis or the slowdown (both models were tested) (CRISIS).

I focused on short panels in which a consistent estimation of fixed effects models is not possible in some standard nonlinear models such as binary logit. I considered a nonlinear panel model for the scalar dependent variable $y_{i t}$, with the regressors $x_{i t}$, in which $i$ denotes the individual firm and $t$ denotes time (for more details, see Cameron and Trivedi, 2009).

\section{RESULTS AND DISCUSSION}

\section{Results of Estimating the Models and Marginal Effects}

The results of estimating the logistic regression models with random effects clearly showed that the probability of implementing innovations was affected by both supply side and demand side factors. Estimating the first model proved that the probability of introducing an innovation depended on internal and external research and development, access to additional funds to conduct the innovation activities, the size of the enterprise measured by the number of employees, and the industry (NACE class) in which the firm operated; see Table 2.

Table 2. Estimation results of the logistic regression model with random effects

\begin{tabular}{|c|c|c|c|c|c|}
\hline Variable & Coef. & Std. Err. & $\mathbf{P}>|\mathbf{z}|$ & \multicolumn{2}{|c|}{$[\mathbf{9 5 \%}$ Conf. Interval] } \\
\hline nacegr & - & - & - & - & - \\
\hline 2 & -0.87944 & 0.18866 & 0.000 & -1.2492 & -0.5097 \\
\hline 3 & -0.12595 & 0.15814 & 0.426 & -0.4359 & 0.1840 \\
\hline 4 & 1.03702 & 0.26006 & 0.000 & 0.5273 & 1.5467 \\
\hline 5 & 0.29720 & 0.13274 & 0.025 & 0.0370 & 0.5574 \\
\hline 6 & 0.88473 & 0.20618 & 0.000 & 0.4806 & 1.2888 \\
\hline 7 & 0.38072 & 0.14385 & 0.008 & 0.0988 & 0.6630 \\
\hline size & - & - & - & - & - \\
\hline 2 & 0.99292 & 0.16890 & 0.000 & 0.6619 & 1.3240 \\
\hline 3 & 2.03812 & 0.18485 & 0.000 & 1.6758 & 2.4004 \\
\hline 1.rdint & 4.73410 & 0.15511 & 0.000 & 4.4300 & 5.0381 \\
\hline 1.rdext & 2.70223 & 0.17635 & 0.000 & 2.4466 & 3.1379 \\
\hline 1.fund & 4.76985 & 0.18267 & 0.000 & 4.4118 & 5.1279 \\
\hline crisis & -0.13483 & 0.06384 & 0.035 & -0.2599 & -0.0097 \\
\hline cons & -2.86071 & 0.19870 & 0.000 & -3.2502 & -2.4713 \\
\hline /nsig2u & 1.47224 & 0.05766 & - & 1.3593 & 1.5853 \\
\hline sigma_u & 2.08782 & 0.06019 & - & 1.9731 & 2.2092 \\
\hline rho & 0.56989 & - & - & 0.4520 & 0.5973 \\
\hline - & - & - & - & Prob>=chibar2 = 0.000 \\
\hline
\end{tabular}

Random effects $u_{i} \sim$ Gaussian Prob. > chi2 = 0.0000; $\mathrm{n}=3691$; Integration method: mvaghermite Integr. pts. 12. Source: own study. 
Table 3. NACE codes and the groups of sectors

\begin{tabular}{|c|l|l|}
\hline Group number & NACE codes & \multicolumn{1}{c|}{ Sector } \\
\hline 1 & $10,11,12$ & Food, beverage, tobacco \\
\hline 2 & $13,14,15$ & Textile products, clothing, manufacture and production of leather \\
\hline 3 & $16,17,18,31$ & Wood, cork, paper, printing, information media, furniture \\
\hline 4 & 20,21 & Chemicals, pharmaceutical substances, medicines and others \\
\hline 5 & $\begin{array}{l}19,22,23,24, \\
25\end{array}$ & $\begin{array}{l}\text { Coke and petroleum refining products, rubber and plastic, mineral } \\
\text { raw materials, ready-made metal products }\end{array}$ \\
\hline 6 & 26,27 & Computers, electronic and optical products, electrical equipment \\
\hline 7 & $\begin{array}{l}28,29,30,32, \\
33\end{array}$ & $\begin{array}{l}\text { Machines, equipment, motor vehicles, trailers, transport equipment, } \\
\text { repair, maintenance and installation of machinery and equipment }\end{array}$ \\
\hline
\end{tabular}

Source: own elaboration based on the Statistics Poland publication on NACE codes.

Table 4. Conditional marginal effects

Model VCE: OIM No of obs: 18,455; Expression: $\operatorname{Pr}($ innov=1), predict(pr); dy/dx w.r.t.: 2.nacegr 3.nacegr 4.nacegr 5.nacegr 6.nacegr 7.nacegr 2.size 3.size 1.rdint 1.rdext 1.fund crisis at:

1.nacegr $=0.1750203$ (mean) 5. nacegr $=0.2851260$ (mean)

2. nacegr $=0.0878895$ (mean) 6. nacegr $=0.6654020$ (mean)

3.nacegr $=0.1368735$ (mean) 7. nacegr $=0.2023842($ mean $)$

4.nacegr $=0.0461664$ (mean)

1.size $=0.0602547$ (mean) 2.size $=0.6937957$ (mean)

3.size $=0.2459496$ (mean)

0.rdint $=0.7962612$ (mean)

1.rdint $=0.2037388$ (mean)

0.rdext $=0.87521$ (mean)

1.rdext $=0.12479$ (mean)

0. fund $=0.8833378$ (mean)

1. fund $=0.1166622$ (mean)

crisis $=0.2$ (mean)

\begin{tabular}{|c|c|c|c|c|c|}
\hline Variable & $\mathbf{d x} / \mathbf{d y}$ & Delta-method Std. Err. & $\mathbf{P}>|\mathbf{z}|$ & \multicolumn{2}{|c|}{ [95\% Conf. Interval] } \\
\hline nacegr & - & - & - & - & - \\
\hline 2 & -0.1282672 & 0.0270784 & 0.000 & -0.181340 & -0.075194 \\
\hline 3 & -0.0185077 & 0.0232328 & 0.426 & -0.064043 & 0.0270278 \\
\hline 4 & 0.1471202 & 0.3524320 & 0.000 & 0.0780449 & 0.2161956 \\
\hline 5 & 0.0434168 & 0.0194034 & 0.025 & 0.0053869 & 0.0811447 \\
\hline 6 & 0.1265472 & 0.0287068 & 0.000 & 0.0702829 & 0.1828116 \\
\hline 7 & 0.0555089 & 0.0209462 & 0.008 & 0.0144551 & 0.0965627 \\
\hline size & - & - & - & - & - \\
\hline 2 & 0.1442111 & 0.0238723 & 0.000 & 0.0974222 & 0.191 \\
\hline 3 & 0.2927306 & 0.0259158 & 0.000 & 0.2419366 & 0.3435246 \\
\hline 1.rdint & 0.5233466 & 0.0094349 & 0.000 & 0.5048545 & 0.5418387 \\
\hline 1.rdext & 0.3474864 & 0.0160376 & 0.000 & 0.3160533 & 0.3789195 \\
\hline 1.fund & 0.4819280 & 0.0091009 & 0.000 & 0.4640906 & 0.4997655 \\
\hline crisis & -0.196870 & 0.0093206 & 0.035 & -0.037955 & -0.001419 \\
\hline
\end{tabular}

* Note: $\mathrm{dy} / \mathrm{dx}$ for factor levels is the discrete change from the base level.

Source: own elaboration based on the PNT-02 data in STATA. 
Table 5. Average marginal effects

Model VCE: OIM No of obs. = 18,455; Expression: $\operatorname{Pr}($ innov=1), predict(pr); dy/dx w.r.t.: 2.nacegr 3.nacegr 4.nacegr 5.nacegr 6.nacegr 7.nacegr 2.size 3.size 1.rdint 1.rdext 1.fund crisis

\begin{tabular}{|c|c|c|c|c|c|}
\hline Variable & $\mathbf{d x} / \mathbf{d y}$ & Delta-method Std. Err. & $\mathbf{P}>|\mathbf{z}|$ & \multicolumn{2}{|c|}{ [95\% Conf. Interval] } \\
\hline nacegr & - & - & - & - & - \\
\hline 2 & -0.079723 & 0.0165971 & 0.000 & -0.112253 & -0.047193 \\
\hline 3 & -0.01219 & 0.0152871 & 0.425 & -0.042152 & 0.0177721 \\
\hline 4 & 0.1080959 & 0.0278646 & 0.000 & 0.053483 & 0.1627094 \\
\hline 5 & 0.0296879 & 0.0131828 & 0.024 & 0.003850 & 0.0555257 \\
\hline 6 & 0.0915586 & 0.0217168 & 0.000 & 0.048995 & 0.1341227 \\
\hline 7 & 0.382507 & 0.0144159 & 0.008 & 0.009996 & 0.0665053 \\
\hline size & - & - & - & - & - \\
\hline 2 & 0.0889518 & 0.0139105 & 0.000 & 0.061687 & 0.1162159 \\
\hline 3 & 0.1982353 & 0.0162788 & 0.000 & 0.1663294 & 0.2301411 \\
\hline 1.rdint & 0.4981822 & 0.010487 & 0.000 & 0.477628 & 0.518737 \\
\hline 1.rdext & 0.3006198 & 0.0178872 & 0.000 & 0.265562 & 0.335678 \\
\hline 1.fund & 0.4714814 & 0.0112194 & 0.000 & 0.449492 & 0.493471 \\
\hline crisis & -0.0131918 & 0.0062442 & 0.035 & -0.025430 & -0.000953 \\
\hline
\end{tabular}

* Note: $\mathrm{dy} / \mathrm{dx}$ for the factor levels is the discrete change from the base level.

Source: own elaboration based on the PNT-02 data in STATA.

Unlike other studies, my analysis captured the occurrence of the negative demand shock in 2008-2010. The results of the model estimation show that the variable Crisis $_{t}$ was significant. Therefore, the likelihood of introducing an innovation by an enterprise is also influenced by the demand factor, i.e. a negative external shock decreases the likelihood of introducing an innovation. This effect is visible for all of the enterprises that operated in the manufacturing sector. The likelihood of introducing innovations increased with the size of the company, a higher expenditure on research and development inside the institution, and higher external funds to conduct research and development.

The analysis of marginal effects enabled me to quantify how likely it was for firms with given characteristics to innovate. Marginal effects can be evaluated either at a specified point for all of the covariates in a model (conditional marginal effects) or at the observed values of the covariates in a dataset and then averaged (average marginal effects). To compute the average marginal effects, the marginal effect is first computed for each observation in the dataset and then averaged. If the sample over which we compute the average marginal effect represents a population, then we estimate the marginal effect for the population. The average marginal effect can be - but will not necessarily always be - close to the marginal effect at the mean that was computed earlier. The differences depend on the distribution of the other covariates. The results also tell us the distribution's effect on the average for populations like the one from which our sample was drawn.

Firstly, I focused on the conditional marginal effects; see Table 4. The mean of all of the covariates is often used as a fixed point, which is sometimes called the marginal effect at the means. Using this approach, we can ask, e.g., how much it increases probability of implementing an innovation by evaluating the marginal effect of being a large company; rather than the first (base) group. At the means of all of the covariates, a large company is 
29.27 percentage points more likely to innovate than a small one. This change in the response supports the discrete change from being a small company (1) to a large company (3). The header of the margins table tells us where the marginal effect was estimated (at the mean). We can also evaluate the marginal effect at the median of the variables.

I grouped the enterprises into seven groups according to their main economic activity indicated by the NACE codes ('PKD class'); see Table 3. At the means of all of the covariates, the companies from the second group were 12 percentage points less likely to innovate than the companies from the first group. Similarly, companies from the third group were 1.85 percentage point less likely to implement a product or process innovation. At the same time, companies grouped into groups four to seven were relatively more likely to introduce an innovation. For enterprises from groups five and seven, the observed effect was moderate. Enterprises in the fifth group were 4.34 percentage points more likely to introduce an innovation, while companies in the seventh group were approximately 5.5 percentage points more likely to do so. The companies in groups four and six had the greatest chances of being innovative. In group four, the companies were 14.7 percentage points more likely to implement an innovation. At the same time, firms from group six were 12.65 percentage points more likely to do so than the firms from the first (base) group.

Grouping the enterprises enabled me to distinguish enterprises with a higher innovation potential from those with a moderate and low innovation potential. Enterprises with the greatest possibilities of implementing innovations were mainly the enterprises from groups four and six. The firms from groups of industries one, three, five, and seven had a moderate chance of being innovative. The lowest chances of introducing innovations had enterprises from group there.

The conditional marginal effect was also computed for expenditures on R\&D internally. The enterprises that had such expenditures were 52.33 percentage points more likely to introduce an innovation. At the same time, companies that purchased R\&D from external sources were 34.74 percentage points more likely to implement an innovation. At the means of all of the covariates, enterprises that allocated additional financial resources for innovation activities were also 48.18 percentage points more likely to innovate.

Although the demand effect was visible, the decrease in the likelihood of innovating was limited. The economic slowdown decreased the possibility of introducing innovation by 1.96 percentage points compared to that of the upswing. However, changes in the business cycle phase also translated into changes in access to external financing, which is crucial from the point of view of implementing innovations.

The results of the average marginal effects analysis provided additional information on the average effects for populations such as the one from which our sample was drawn; see Table 5. On average, the probability of innovating decreased 7.97 percentage points for the enterprises from group two. Enterprises from group three were, on average, 1.22 percentage points less likely to innovate. At the same time, enterprises from groups five and seven were, on average, 2.96 and 3.83 percentage points more likely to introduce innovations, respectively. Companies that operated in the industries which were grouped in groups four and six were, on average, 10.81 and 9.26 percentage points more likely to implement innovations.

The average marginal effects also provided me with information on the impact of the size of the company on the probability of its introducing innovation. The probability of 
innovation for large companies was 19.82 percentage points higher than for a small company and 8.89 percentage points higher for a medium-sized company compared to a small one. On average, spending internally on R\&D increased the likelihood of introducing an innovation by 49.82 percentage points, while the acquisition of R\&D from external sources increased it by 30.06 percentage points. Enterprises that increased funding for innovation activities in a given period were, on average, 47.15 percentage points more likely to introduce an innovation. Meanwhile, the average occurrence of a negative external shock led to a decrease in the probability of innovation of 1.3 percentage point.

\section{Results of the Estimation of Second Model}

The regressors in the logistic regression model did not take into account all of the information provided by the PNT-02 study regarding the current and past innovation activity of enterprises, the anticipated effects of this activity, or the factors hindering it. The impact of the crisis - especially on the cooperation, strategy, or the attitude towards uncertainty - was not captured in the first model.

The composed indicator that was presented in the previous sections can be used as a regressor in the second model. When calculating the indicator, all of the dimensions in the nine categories were included. However, for the first two categories, we should emphasise that only the history of introducing innovations by a given company was taken into account in order to capture the persistence of innovations.

Table 6. Estimation results of the second logistic regression model with random effects Random effects $u_{i} \sim$ Gaussian Prob. > chi2 = 0.0000; $\mathrm{n}=3691$; Integration method: mvaghermite Integr. pts. 12

\begin{tabular}{|c|c|c|c|c|c|}
\hline Variable & Coef. & Std. Err. & $\mathbf{P}>|\mathbf{z}|$ & \multicolumn{2}{|c|}{ [95\% Conf. Interval] } \\
\hline indic & 28.3128 & 0.6957012 & 0.000 & 26.94925 & 29.67635 \\
\hline 1.crisis & -0.926047 & 0.1025085 & 0.000 & -1.12696 & -0.725134 \\
\hline cons & -1.76539 & 0.0705064 & 0.000 & -1.90358 & -1.62720 \\
\hline /Insig2u & -0.2606403 & 0.2405641 & - & -0.732137 & 0.210856 \\
\hline sigma_u & 0.8778144 & 0.1055853 & - & 0.693455 & 1.111186 \\
\hline rho & 0.1897727 & 0.0369889 & - & 0.127529 & 0.272894 \\
\hline- & - & - & - & \multicolumn{3}{|c}{ Prob>=chibar2 $=0.000$} \\
\hline
\end{tabular}

Source: own elaboration based on the PNT-02 data in STATA.

Table 7. Average marginal effects

Model VCE: OIM No of obs. = 18,455; Expression: $\operatorname{Pr(innov=1),~predict(pr);~dy/dx~w.r.t.:~indic~1.crisis~}$

\begin{tabular}{|c|c|c|c|c|c|}
\hline Variable & $\mathbf{d x} / \mathbf{d y}$ & Delta-method Std. Err. & $\mathbf{P}>|\mathbf{z}|$ & \multicolumn{2}{|c|}{ [95\% Conf. Interval] } \\
\hline Indic & 0.8717665 & 0.0110072 & 0.000 & 0.8501928 & 0.893340 \\
\hline 1.crisis & -0.0284984 & 0.0030379 & 0.000 & -0.034452 & -0.022544 \\
\hline
\end{tabular}

* Note: $\mathrm{dy} / \mathrm{dx}$ for the factor levels is a discrete change from the base level.

Source: own elaboration based on the PNT-02 data in STATA.

I estimated the model using random-effect logistic regression on the panel of 3691 firms in the five periods; see Table 6. Then, I computed the average marginal effects as was explained above; see Table 7. On average, the effects of a negative shock in 2008-2010 was 
higher than was estimated in the first model. On average, when affected by a negative demand shock, the enterprises were 2.85 percentage points less likely to innovate. The higher the value of the indicator, the more likely the enterprise was, on average, to innovate. This can be interpreted as evidence that companies that conduct innovation activities internally and cooperate with other companies in innovation development are more likely to implement innovations. Firms that had already implemented innovations in the past are also more likely to innovate. The lower the number of prematurely terminated and unfinished projects, the more efficient the companies were and the more likely they would succeed in the future. The values of an indicator also capture the expenditures on R\&D, machinery, technical equipment, staff training, and marketing related to the introduction of new or significantly improved products. The firms that had higher expenditures, external funding, and public financial support had a greater chance of implementing innovations. Indirectly, the probability of innovation also depended on the previous experience in commercialization, obstacles to innovations, and the probability of generating the desired effects.

The indicator values were calculated for the 3691 companies that had reported in all five editions of the PNT-02 survey. The values of indicators were reported for seven groups of firms; see the appendix in the repository. I computed the predicted probabilities for each company. I was particularly interested in the predicted probabilities of the innovations of the firms in the seven NACE groups in relevant periods.

For the first group the percentage of enterprises that purchased innovations from other enterprises and institutions on the market during the crisis decreased. Moreover, there was a decrease in the percentage of companies that were focused on introducing an innovation on their own; for which product or process development and commercialization were conducted within the enterprise. During the economic recovery, there was a higher mobilization of funds both among the companies that had purchased and conducted an innovation activity within the enterprise, which translated into a higher probability of success, i.e. the introduction of an innovation.

In 2004-2006, on average, the firms in the first NACE group had a 0.4841 probability of introducing an innovation. In 2006-2008 it was 0.4881, during the crisis of 2008-2010 it was 0.4053 , while in $2008-2010$ the number was 0.4629 . In the last period, this probability was lower than was expected, taking into account the expansionary phase of the business cycle, i.e. 0.4025 . In the latter group, innovation activity is largely procyclical. In the last period under study, I observed the effect of approaching end of the business cycle's expansionary phase.

For the second group, the percentage of enterprises that had focused on purchasing from other enterprises and institutions on the market was significantly higher than in the first group in each of the periods. During the economic slowdown, a higher percentage of firms were neutral towards innovation. The situation was similar for enterprises that carried out innovation activities internally. However, for the latter, the percentage of the type of company whose attitude changed to neutral was lower than for companies that had been purchasing ready solutions from other entities. The probability of the successful introduction of an innovation by the companies conducting innovation activity significantly decreased during economic slowdown of 2008-2010 and in 2012-2014. On average, in 2004-2006, the firms that conducted innovation activities had a probability of introducing an innovation of 0.4567 . In 2006-2008, it was 0.4315 , while during the crisis, it was only 
0.4175. During the recovery, it was 0.4407 , while in $2012-2014$, the probability of introducing an innovation reached the low of 0.4003 . The innovation activity of these companies was procyclical for the firms from the first group. However, the worse position of the companies from the second group compared to the first group was due to a higher percentage of companies that ceased their innovation activity; i.e., they had switched to being neutral towards innovation activity during the crisis.

We should mostly pay attention to the occurrence of the structural problems in the above group of enterprises, which negatively affected their performance and the development of innovations. Economic policy whose aim is to support this type of enterprises should be designed to correct these structural problems and not only to counteract the effects of negative demand shocks. For the companies from the third group, there was a decrease in innovation activity and cooperation among the companies that conducted this type of activity internally. The percentage of companies that were buying innovations externally also slightly decreased during the crisis, which was largely connected with the reduction of funding in 2008-2010. On average, the probability of introducing innovations by enterprises decreased in 2004-2012 and increased slightly in 2012-2014. For this group, the innovation activity of the companies was mostly acyclic.

The firms in the fourth group had on average a 0.4985 probability of introducing an innovation in 2004-2006. In 2006-2008 it was 0.4883 , in 2008-2010 it was 0.4404 , in 2010-2012-0.4665, while in 2012-2014 the number was 0.3503. In this group, the percentage of companies that were interested in purchasing ready-made solutions was smaller. During the crisis, the percentage of buyers from other enterprises and institutions slightly dropped. From the beginning of the crisis until 2014, the percentage of companies that were interested in partially conducting innovation within companies grew (a moderate degree of innovation activity). In the fourth group, on average, the probability of introducing innovations decreased from period to period. The percentage of companies that were strongly focused on internal innovation activity steadily decreased (firms with indicator values above 0.5 ). Being in this group could explain the higher probability of introducing innovations in the whole sample.

In the fifth group, on average, a firm had a probability of introducing innovation of 0.4613 in 2004-2006 and 0.4925 in 2006-2008. The probability of implementing an innovation began to decrease at the beginning of the crisis: it was 0.4423 in 2008-2010, 0.4337 in 2010-2012, and 0.4151 in 2012-2014. The innovation activity of the firms in the fifth group was similar to that of the firms in the first group; however, the percentage of firms that conducted innovation activity internally was, on average, higher among the former compared to the latter.

In the sixth group, there was an intensification of the internal innovative activity of the companies despite the crisis (challengers). There was a slight decrease in the activity of the companies during the crisis, but only among those for whom the indicator values were the highest; i.e. above 0.6 . Most of these types of companies were involved in countercyclical innovation activities. Lower percentages of the companies operating internally - with an indicator value below 0.6 - and purchasing externally were observed in the period preceding the crisis (2006-2008). In group six, on average, a company had a 0.4493 probability of introducing an innovation in 2004-2006 and 0.4091 in 2006-2008. The probability of introducing an innovation by firms in this group during the crisis was the highest 
in all of the groups (0.4806). The probability of introducing innovations after the crisis was relatively lower; it was 0.3944 in 2010-2012 and 0.3823 in 2012-2014, respectively. The innovation activity of these companies was mostly countercyclical.

For the last group of enterprises, the companies that were most focused on innovation activity internally - with indicator values above 0.5 - were the most active in the period preceding the crisis (2006-2008). The role of the internally active innovation companies increased during the crisis (up to 0.45), while the percentage of external buyers dropped. On average, the probability of introducing an innovation by a company in this sector was 0.4610 in 2004-2006. It decreased in the period preceding the crisis and during the crisis to 0.4291 and 0.4081 , respectively. However, innovation activity increased during the recovery. The probability of introducing an innovation by a medium-sized firm in 2010-2012 was, respectively, 0.4766 and 0.4228 in the 2012-2014.

\section{CONCLUSIONS}

The aim of this study was to analyse the differentiation of the innovation activities and strategies of Polish manufacturing companies between 2004-2014. The study focused on both the supply-side and demand-side factors that influence the decisions of firms to innovate.

I used the proprietary disaggregated data from the PNT-02 surveys, which were obtained from the Statistics Poland, which overlap with the Community of Innovation Survey (CIS). In the study, I analysed all of the information that had been provided by the entire population of large and medium-sized enterprises, along with samples of small companies in Poland. I studied how the economic slowdown in Poland in 2008 affected the innovation activities and commercialization of the firms. Thus, I performed a detailed statistical analysis of the changes in the linkages in the innovation processes, the sources of information that were used by the companies in a specific phase of the business cycle, the forms of cooperation between the entities on the market, along with funding and human resources. Moreover, I commented on the objectives, obstacles, and outcomes of innovation.

Then, I used the information in the survey to develop indicators of the innovation strategies. To compute the values of indicator, I developed a complex algorithm that teaches a machine how to interpret the data that had been provided by the firms in the respective editions of the survey. The analysis of the values of the indicators revealed that - irrespective of the period under study - a high percentage of the firms were characterised by a neutrality towards innovations. The impact of the crisis was greater on companies that were more willing to purchase a ready-made solution on the market or to imitate than on the firms that were developing product and process innovations internally.

Next, I presented the results of the econometric analysis that had been performed on a panel of 3691 firms that had reported in all five of the surveys. I used random-effect logistic regression to uncover the factors behind the higher probability of a firm innovating. The analysis suggested that both supply-side factors and the occurrence of a negative shock have an impact on the probability of innovating. The likelihood of introducing innovations increased with the size of the company, a higher expenditure on research and development internally and externally, and an increase in internal and external funds for innovation activities. The probability of innovation also depended on a firm's NACE group.

A joint analysis of the indicators for innovation strategy and the probability of innovation enabled us to determine the groups of firms whose innovation activity was procyclical, 
countercyclical and acyclic, respectively. Our analysis is of particular relevance for the Polish National Innovation System (NIS). Although in most cases the innovation activity of the firms was procyclical, there also appeared groups of firms that were challengers, i.e. such that introduced innovations and dynamically conducted innovation activities during an economic slowdown or even a crisis. Those firms should be targeted differently than companies that require structural adjustments.

The main research limitation is related to the restricted access to data after 2014. Future research should focus on testing the procyclicality and countercyclicality of innovation activities and strategies of manufacturing firms in the long period, i.e. up to 2019. In the parallel study, I focused on the problem of aggregation bias that may affect the results and incorrectly suggest procyclicality of innovation activity of companies in aggregates.

\section{REFERENCES}

Antonioli, D., Bianchi, A., Mazzanti, M., Montresor, S, \& Pini, P. (2013). Innovation Strategies and Economic Crisis: Evidence from Firm-level Italian Data. Economia Politica, 30(1), 33-68. https://doi.org/ 10.1428/73099

Archibugi, D., \& Filippetti, A. (2011). Is the Economic Crisis Impairing Convergence in Innovation Performance across Europe? JCMS-Journal of Common Market Studies, 49(6), 1153-1182. https://doi.org/10.1111/j.1468-5965.2011.02191.x

Archibugi, D., \& Filippetti, A. (2012). Innovation and economic crisis. Lessons and prospects from the economic downturn. Routledge studies on global competition. Abigdon, England: Francis \& Taylor group.

Archibugi, D., Filippetti, A., \& Frenz, M. (2012). The effect of the financial crisis on patterns of innovation investment in Europe: an analysis of Innobarometer. Birkbeck University of London Presentation.

Archibugi, D., Filippetti, A., \& Frenz, M. (2013). The impact of the Economic Crisis on Innovation: Evidence from Europe. Technological Forecasting and Social Change, 80(7), 1247-1260. https://doi.org/10.1016/j.techfore.2013.05.005

Archibugi, D., Filippetti, A., \& Frenz, M. (2013a). Who Innovates Out of the Crisis?. The European Business Review, (n.d.), 58-60.

Archibugi, D., Filippetti, A., \& Frenz, M. (2013b). Economic crisis and innovation: Is destruction prevailing over accumulation? Research Policy, 42(2), 303-314. https://doi.org/10.1016/j.respol.2012.07.002

Cameron, C., \& Trivedi, P. (2009). Microeconometrics using STATA. College Station, Texas, US: Stata Press.

Castellaci, F. (2008). Technological paradigms, regimes and trajectorie: Manufacturing and service industries in a new taxonomy of sectoral patterns of innovation. Research Policy, 37, 978-994.

Correa, P., \& lotty, M. (2010). Will the Crisis Affect the Economic Recovery in Eastern European Countries? Evidence from Firm Level Data. The World Bank Policy Working Paper 5278.

Damanpour, F., \& Wischnevsky, J.D. (2006). Research on innovation in organizations: Distinguishing innovation-generating from innovation-adopting organizations. Journal of Engineering and Technology Management, 23(4), 269-291. https://doi.org/10.1016/j.jengtecman.2006.08.002

de Jong, J.P.J., \& Marsili, O. (2006). The fruit flies of innovations: A taxonomy of innovative small firms. Research Policy, 35, 213-229.

Frenz, M., \& Lambert, R. (2010). Connected Innovation: An International Comparative Study that Identifies Mixed Modes of Innovation, Paper to be presented at the Summer Conference 2010 
on Opening Up Innovation: Strategy, Organization and Technology at Imperial College London Business School, June 16-18.

Giebel, M., \& Kraft, K. (2017). External financing constraints and firm's innovative activities during the financial crisis. ZEW Discussion Paper, 17-064, 1-27.

Hardy, B., \& Sever, C. (2020). Financial crisis and innovation. BIS Working Paper, 846, 1-49.

Holl, A., \& Roma, R. (2016). Persistence of innovative activities in times of crisis: the case of Basque Country. European Planning Studies, 24(10), 1863-1883.

Innovation in the crisis and beyond. (2012). OECD Science, Technology and Industry Outlook. Paris, France.

Jensen, M.B., Johnson, R, Lorenz, E., \& Lundvall, B.A. (2007). Forms of Knowledge and Modes of Innovation. Research Policy, 36(5), 680-693.

Leiponen, A., \& Drejer, I. (2007). What exactly are technological regimes? Intra-industry heterogeneity in the organization innovation activities. Research Policy, 36(8), 1221-1238.

Llerene, P., \& Oltra, V. (2002). Diversity of Innovative Strategy as a Source of Technological Performance. Structural Change and Economic Dynamics, 13(2), 179-201.

Lenart, Ł., \& Pipień, M. (2013a) Almost Periodically Correlated Time Series in Business Fluctuations Analysis: the case of Poland. Acta Physica Polonica A, 123(3), 70-86. https://doi.org/10.2139/ssrn.2006343

Mintzberg, H. (1988). Generic strategies: Towards a comprehensive framework. Advance in Strategic Management, 5, 1-16.

Oslo Manual. (2005). The Measurement of Scientific and Technological Activities. Guidelines for Collecting and Interpreting Innovation Data. OECD and Eurostat Joint Publication. Paris, France.

Pavitt, K. (1984). Sectoral patterns of technical change: towards a taxonomy and a theory. Research Policy, 13(6), 343-373.

Peneder, M. (2003). Industry Classifications: Aim, Scope and techniques. Journal of Industry, Competition and Trade, 3, 109-12.

Pipień, M., Wdowiński, P., \& Kaszowska, J. (2018). Identyfikacja cech cyklu finansowego i analiza jego synchronizacji z cyklem koniunkturalnym. Materiały i Studia, 332, 4-67.

Som, O., Dreher, C., \& Maloca, S. (2010), Innovation Patterns of Non-R\&D Performing Firms in the German Manufacturing Industries. An Evolutionary Approach to Heterogeneity in Firms' Innovation Strategy, paper for the 13th Conference of the International Schumpeter Society, Aalborg University, Denmark, June 21-24.

Srholec, M., \& Versagen, B. (2008). The Voyage of the Beagle in Innovation System Land. Explorations on Sectors, Innovation, Heterogeneity and Selection. Centre for Technology, Innovation and Culture, University of Oslo

Wziątek-Kubiak, A., \& Pęczkowski, M. (2013). Źródła i bariery ciągłości wdrażania innowacji przez polskie przedsiębiorstwa, In J. Sokołowski \& M. Rękas (Eds.), Ekonomia (1st ed., pp. 872-883). Wrocław, Poland: Prace Naukowe Uniwersytetu Ekonomicznego we Wrocławiu 305.

Wziątek-Kubiak, A., Balcerowicz, E., \& Pęczkowski, M. (2013a). Differentiation of Innovation Strategy of Manufacturing Firms in the New Member States. Cluster Analysis on Firm Level Data. Argumenta Oeconomica, 2(31), 117-149. 


\section{Author}

\section{Jagoda Kaszowska-Mojsa}

Researcher at the Institute of Economics at the Polish Academy of Sciences and at the National Bank of Poland; Assistant Professor at the Cracow University of Economics, Poland (Macroeconomics Department). Graduated from the University of Alcalá (Spain) and Jagiellonian University (Poland), received her PhD degree in Economics at the Cracow University of Economics (Poland) under the supervision of Prof. A. Wojtyna. A recipient of the Fulbright Junior Advanced Research Award to conduct research in the United States of America, Internship of the Governor of National Bank of Poland, and National Science Centre grants. Her research interests include computational economics, business and financial cycles, innovation strategies, financial innovations, and systemic risk.

Correspondence to: Dr. Jagoda Kaszowska-Mojsa, Institute of Economics, Polish Academy of Sciences, Nowy Świat 72, 00-330 Warsaw, email: jagoda.kaszowska@inepan.waw.pl

ORCID (1) http://orcid.org/0000-0001-6261-5084

\section{Acknowledgements and Financial Disclosure}

The article came into being within project no. 2015/17/B/HS4/02742 entitled "The Differentiation of Innovation Strategies of Polish Manufacturing Firms as an Effect of Changes in Macroeconomic Environment," which was financed by the National Science Centre. This article was presented as an academic paper at 16th International Conference "Developments in Economic Theory and Policy," which was organised in Bilbao on 27-28 June 2019. The PNT-02 data was provided by the Statistics Poland office in Szczecin, which is not responsible for the conclusions contained in the publication. The specific data and values of indicators for specific groups are available in the external repository on ResearchGate.

I would also like to thank the anonymous referees for their useful comments, which permitted her to increase the value of this article.

\section{Copyright and License}

This article is published under the terms of the Creative Commons

Attribution - NoDerivs (CC BY-ND 4.0) License

http://creativecommons.org/licenses/by-nd/4.0/

Published by Cracow University of Economics - Krakow, Poland 